Sains Malaysiana 46(8)(2017): 1279-1284

http://dx.doi.org/10.17576/jsm-2017-4608-13

\title{
Antibacterial Activity of Alkaloid Extracts from Ochrosia oppositifolia
}

(Aktiviti Antibakteria Ekstrak Alkaloid daripada Ochrosia oppositifolia)

\author{
PUTERI I.A.M. MAHMUD*, W.A. YAACOB \& NAZLINA IBRAHIM
}

\begin{abstract}
Ochrosia oppositifolia can be found along the coastline and is locally known as 'Mempelam pasih' or 'Mangga laut'. In this study, the alkaloids from the leaves, stem-bark and roots were extracted and tested for their antibacterial activity. So far, no previous studies have been carried out to determine the antibacterial potential of the extracts. Each extract was tested using disc-diffusion and minimum inhibitory concentration (MIC) methods. The highest inhibitory diameters shown by $10 \mathrm{mg} / \mathrm{mL}$ extracts of the leaves and stem-bark against Staphylococcus aureus and the roots against MRSA

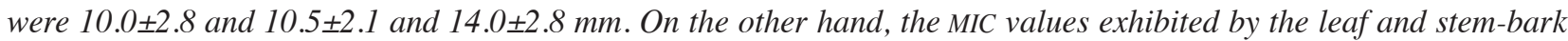
extracts against Bacillus subtilis, Salmonella thyphimurium and Serratia marcescens and the root extract against Vibrio fluvialis were 3.75 and 0.94 and $0.12 \mathrm{mg} / \mathrm{mL}$. This study broadens the bioactivity potential of the plant and the information obtained can be utilized for pharmacological purposes.
\end{abstract}

Keywords: Alkaloid extract; antibacterial activity; disc diffusion; minimum inhibitory concentration; Ochrosia oppositifolia

\section{ABSTRAK}

Ochrosia oppositifolia adalah tumbuhan pesisir pantai dan dikenali orang tempatan sebagai 'Mempelam pasih' atau 'Mangga laut'. Dalam kajian ini, alkaloid daripada daun, kulit dan akar diekstrak dan diuji aktiviti antibakteria mereka. Tiada kajian terdahulu yang dijalankan setakat ini bagi menentukan potensi aktiviti ekstrak tersebut. Setiap ekstrak diuji menggunakan kaedah resapan-cakera dan kepekatan perencatan minimum (MIC). Diameter perencatan tertinggi ditunjukkan oleh ekstrak $10 \mathrm{mg} / \mathrm{mL}$ bagi daun dan kulit terhadap Staphylococcus aureus dan akar terhadap SARM adalah

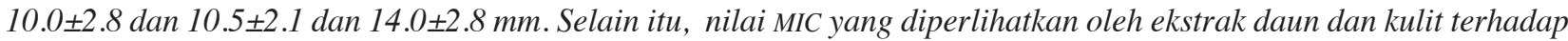
Bacillus subtilis, Salmonella thyphimurium dan Serratia marcescens serta ekstrak akar terhadap Vibrio fluvialis adalah 3.75 dan 0.94 dan $0.12 \mathrm{mg} / \mathrm{mL}$. Kajian ini memperluaskan potensi bioaktiviti tumbuhan tersebut dan maklumat yang diperoleh dapat digunakan bagi tujuan farmakologi.

Kata kunci: Aktiviti antibakteria; ekstrak alkaloid; kepekatan perencatan minimum; Ochrosia oppositifolia; resapan-cakera

\section{INTRODUCTION}

Ochrosia oppositifolia or also known as Calpicarpum oppositifolium is of the family Apocynaceae. It is a small tree with stout branches, leaves fleshy with whorls of 7.5$10 \mathrm{~cm}$ and obovate in shape $10-25 \mathrm{~cm}$ long. Their flowers are white and the fruits or drupes are ovoid in shape 5-7 $\mathrm{cm}$ long (Ridley 1894). The timber is moderately hard and grained (Burkill 1966). It was first found in areas ranging from the Mascarene Island to Polynesia. Observed along the coastline in Singapore a century ago, it still occurs in the group of islands in Langkawi, Malaysia (Gamble 1922).

The roots were taken as an antidote for eating poisonous fishes and crustaceans (Gamble 1922). In Vietnam, the local people credited the bark, wood and leaf with febrifugal and stomachic properties (Van Valkenberg \& Bunyapraphatsara 2001). Meanwhile in the Seychelles, a bitter bark decoction is taken to purify the blood, as an appetizer, purgative and carminative and in high doses as an abortifacient. A leaf decoction is also used to wash the abdomen of women after childbirth (Gurib \& Brendler 2004). Furthermore, local people in Acheh used the decoction of the stem-bark to treat malaria (Susiarti 2006). Ochrosia oppositifolia also has similar uses in Southeast Asian countries (Van \& Hendrian 2001).

In previous study, two compounds of neisosposinine and reserpinine were isolated from the bark and leaves of Ochrosia oppositifolia. While, another indole alkaloids of isoreserpiline and alkaloid D were also isolated from the bark and leaves of $O$. oppositifolia, respectively. Two ferulic acid esters were another compounds found in the bark of O. oppositifolia (Nasab 2013; 2012). All extracts and pure compounds were tested for antiplasmodial activity in which the hexane bark extract showed highest activity with $\mathrm{IC}_{50} 0.0505 \mu \mathrm{g} / \mathrm{mL}$ and the alkaloid $\mathrm{D}$ was the most potent compound with $\mathrm{IC}_{50} 0.0123 \mu \mathrm{mol} / \mathrm{L}$ (Nasab 2012). Other related study reported that screening of the appropriate extracts of Ochrosia maculata elicited both oncolytic and neurosedative activities. The former was found to be associated with 9-methoxyellipticine 
while the latter with reserpine. 9-Methoxyellipticine possesses a moderate degree of potency as an antitumor agent expressed by its activity against several of the solid mouse neoplasm (Svobodo et al. 1968).

The above findings showed that the local had used parts of the tree for treatments of various health conditions. The above studies also showed that the tree of Ochrosia oppositifolia and the related genus contains profound alkaloids with various promising potency of bioactivity such as antiplasmodial and antitumor. However, there is still many other bioactivity potential of $O$. oppositifolia that not yet discovered. Therefore, in this study, the antibacterial potential of the alkaloid extracts of $O$. oppositifolia against four Gram-positive and five Gram-negative bacteria were evaluated as bacterial resistance against existing drugs nowadays are steadily increasing. Thus, there are needs to overcome this antibiotic resistance of pathogenic species. Furthermore, as reported earlier, $O$. oppositifolia plant extract chemically consists of indole alkaloids which are nitrogen bearing structures known to be pharmacologically active.

\section{MATERIALS AND METHODS}

\section{PLANT MATERIALS COLLECTION AND IDENTIFICATION}

The studied plant parts of Ochrosia oppositifolia were leaves, stem-bark and roots. They were collected from Pulau Pangkor, Perak, Malaysia on July 2014. The plant species were identified by Mr. Sani Miran, a botanist at Universiti Kebangsaan Malaysia. For further reference, a plant voucher specimen of WYA517 was deposited at the Universiti Kebangsaan Malaysia Herbarium (UKMB).

\section{SCREENING OF ALKALOIDS}

The alkaloids for different parts of the plant were detected by using Mayer precipitating reagent $\left(\mathrm{K}_{2} \mathrm{HgI}_{4}\right)$ described by Culvenor and Fitzgerald (1963) and Dragendoff's reagent.

\section{EXTRACTION OF ALKALOIDS}

The leaves, stem-bark and roots of Ochrosia oppositifolia were air dried, the latter was cut into small pieces and each of the three plant materials was grounded into powder by using a grinder. In an empty amber solvent glass bottle, $300 \mathrm{~g}$ of each powder was soaked in $1.5 \mathrm{~L}$ methanol for three days with regular shaking. The methanol solution was filtered using cotton wool and the filtrate evaporated under reduced pressure using Buchi rotary evaporator at less than $40^{\circ} \mathrm{C}$ until about one tenth of its original volume remained (Neli et al. 2011). The concentrated solutions were used for the extraction of alkaloids following Hadi and Bremner (2001) with minor modification to yield $0.20(0.07), 0.70(0.23)$ and $0.20 \mathrm{~g}(0.07 \%)$ of the leaf, stem-bark and root alkaloid extracts. They were stored below $4^{\circ} \mathrm{C}$ prior to use.

\section{PREPARATION OF EXTRACTS FOR ANTIBACTERIAL ASSAY}

Stock solutions of the test extracts were prepared from 10 $\mathrm{mg} / \mathrm{mL}$ for disc-diffusion method (in methanol) and 30 $\mathrm{mg} / \mathrm{mL}$ for minimum inhibitory concentration method (in DMSO). For disc-diffusion method, blank $6 \mathrm{~mm}$ diameter discs were prepared from the cut out of filter paper Whatman No.2 and sterilized using autoclave machine at $120-124^{\circ} \mathrm{C}$ for $1-2 \mathrm{~h}$ before being dipped into $10 \mathrm{mg} / \mathrm{mL}$ of each of the test extract solutions and allowed to air-dry in a plastic Petri-dish at room temperature. The air-dried discs were prepared before use.

\section{BACTERIAL STRAINS}

Bacterial strains of four Gram-positive of Staphylococcus aureus ATCC 25923, Bacillus subtilis ATCC 11774, B. thuringiensis ATCC 10792, methicillin resistant $S$. aureus (MRSA) and bacterial strains of five Gramnegative of Escherichia coli ATCC 10536, Salmonella thyphimurium ATCC 51812, Serratia marcescens ATCC 13880, Vibrio cholera and V. fluvialis were obtained from the Microbiology Laboratory culture collection, School of Biosciences and Biotechnology, Faculty of Science and Technology, Universiti Kebangsaan Malaysia.

\section{PREPARATION OF CULTURE MEDIA FOR ANTIBACTERIAL ASSAY USING MUELLER-HINTON AGAR (MHA) AND MUELLER-HINTON BROTH (MHB)}

To prepare MHA, $800 \mathrm{~mL}$ distilled water was added to a Schott bottle (1 L) containing $19 \mathrm{~g}$ of Mueller-Hinton agar powder. Meanwhile, to prepare MHB, $200 \mathrm{~mL}$ distilled water was added to a Schott bottle $(500 \mathrm{~mL})$ containing $4.4 \mathrm{~g}$ of Mueller-Hinton broth powder. As for minimum inhibitory concentration method, $200 \mathrm{~mL}$ of Tween 80 solution $(0.5 \% \mathrm{v} / \mathrm{v})$ was used instead of distilled water and added with $2.6 \mathrm{~g}$ of Mueller-Hinton broth powder to prepare the MHB solution. The mixtures were then shaken thoroughly to dissolve the powder. Then, $10 \mathrm{~mL}$ of each of the two MHB solutions were poured into 9 universal bottles $(20 \mathrm{~mL})$ and $5 \mathrm{~mL}$ of the same solutions were then poured into 9 universal bottles $(10 \mathrm{~mL})$. After that, the MHA and 36 bottles of MHB solutions were sterilized for 1-2 $\mathrm{h}$ at 120 $124^{\circ} \mathrm{C}$ using the autoclave machine. The sterilized MHB solutions were kept at $4^{\circ} \mathrm{C}$ until use and the MHA solution was used to prepare agar plates.

\section{PREPARATION OF AGAR PLATES}

The laminar hood was first sterilized with $70 \%$ ethanol. Then all the empty disposable commercial plastic Petridishes (diameter $9 \mathrm{~cm}$ ) were assembled in the laminar hood and sterilized using UV light for 15-30 min. Later, the hot sterilized MHA solution was poured into each of the dishes enough to cover their surfaces; they were cooled under UV light for 15-30 min to form agar. Finally, the plates were concealed with their covers and stored in the cool room to prevent contamination until use. 


\section{PREPARATION OF BACTERIAL INOCULUMS}

The sterilized 9 universal bottles with $5 \mathrm{~mL}$ of each of the two MHB solutions were seeded with bacteria from the pure culture stocks using a sterilized wire-loop and incubated at $37^{\circ} \mathrm{C}$ for $24 \mathrm{~h}$ to obtain the cultures. After that, $300 \mu \mathrm{L}$ of each culture were taken and put into the 10 $\mathrm{mL}$ sterilized MHB solution prepared earlier in the $20 \mathrm{~mL}$ universal bottle. The turbidity of culture was measured and standardized against the McFarland 0.5 (optical density of 0.13 at $625 \mathrm{~nm})$.

\section{DISC-DIFFUSION ASSAY}

The disc-diffusion assay according to CLSI (2009) and Scorzoni et al. (2007) was carried out to determine antibacterial activity of the alkaloid extracts by measuring the inhibition diameters. The bacteria suspensions in MHB solution (distilled water) were loaded on a sterile cotton swabs and streaked over the dried surface of MHA plates for inoculation. The sterile filter paper discs previously impregnated with each of the extracts $(10 \mathrm{mg} / \mathrm{mL})$ were then placed on the inoculated agar. The plates were incubated at $37^{\circ} \mathrm{C}$ for $24 \mathrm{~h}$. The antibacterial activity was determined by measuring the diameter of inhibition zone in millimeter including the disc diameter against the bacteria. All tests were carried out in triplicate. Streptomycin (10 $\mu \mathrm{g})$, vancomycin $(30 \mu \mathrm{g})$, penicillin $(30 \mu \mathrm{g})$, kanamycin $(30 \mu \mathrm{g})$ and tetracycline $(30 \mu \mathrm{g})$ were used as positive controls. A disc which was impregnated with methanol and air-dried was used as negative control.

\section{MINIMUM INHIBITORY CONCENTRATION}

MIC was used to determine the lowest concentration of the assayed antibacterial agent that, under defined test conditions, inhibits the visible growth of the bacteria (Irith et al. 2008). MIC was evaluated on bacterial strain that showed sensitivity to the extracts in the disc-diffusion assay according to Irith et al. (2008) and CLSI (2009). MIC was carried out using broth dilution assay with two-fold serial micro-dilution in 96-well microplate. A $100 \mu \mathrm{L}$ of 30 $\mathrm{mg} / \mathrm{mL}$ DMSO solution of each of the test alkaloid extracts was loaded into the first well and serially two-fold diluted to obtain the extract concentrations down to $0.12 \mathrm{mg} /$ $\mathrm{mL}$. A $50 \mu \mathrm{L}$ of the MHB solution (Tween 80 ) of bacterial inoculums was then dispensed using micropipette into each of the above loaded well. Each microplate was only used for one bacterium. All tests were carried out in triplicate. For positive controls, chloramphenicol of two-fold dilution from 128 down to $0.25 \mu \mathrm{g} / \mathrm{mL}$ and vancomycine of twofold dilution from 32 down to $0.06 \mu \mathrm{g} / \mathrm{mL}$ were used. The preparation of these antibiotic stock solutions and their ranges for MIC determination was done according to suggestions from literature (Jennifer 2006). Meanwhile, the last three wells of the line were used as negative control by filling $50 \mu \mathrm{L}$ of the above bacteria inoculums and $50 \mu \mathrm{L}$ DMSO. As for the growth control, the well was filled with $100 \mu \mathrm{L}$ of the blank MHB solution and $50 \mu \mathrm{L}$ of $30 \mathrm{mg}$ /
mL DMSO extract solution. The microplates were covered with aluminum foil and incubated at $37^{\circ} \mathrm{C}$ for $16-24 \mathrm{~h}$ in an incubator.

\section{DETERMINING BACTERIAL GROWTH USING MTT ASSAY}

MTT (3-(4,5-dimethylthiazol-2-yl)-2,5-diphenyltetrazolium bromide) is a tetrazolium dye (greenish yellow) which can be reduced by the live bacteria into an insoluble purple formazan. This reagent therefore can be used to differentiate between the live and the dead bacteria (Stevens \& Olsen 1993). MTT was prepared by dissolving in a phosphate-buffered saline (PBS) solution at $0.2 \mathrm{mg} /$ $\mathrm{mL}$. In this study, the MTT assay was incorporated into the MIC method to visually differentiate between the live (the colour of mixture turns purple) and the dead bacteria (the colour of mixture remains). After 16-24 h incubation in the MIC method, $50 \mu \mathrm{L}$ of the MTT reagent were added into each well. The colour development was observed and recorded after $2 \mathrm{~h}$ incubation (Figures 1-4).

\section{RESULTS AND DISCUSSION}

It is well known that alkaloids have many pharmacological properties such as antitumor, cytotoxic, antiprotozoa, antimicrobial and antiparasitic properties (Neli et al. 2011). Some other studies also found that Neisosperma oppositifolia (Kartini et al. 2010), Ochrosia maculata (Svobodo et al. 1968) and Ochrosia sandwicences (Jordan $\&$ Werner 1965) have profound alkaloids content. All these studies showed that the alkaloids presence give promising bioactivity such as antitumor and vasorelaxtant effect.

In this study, the alkaloid extracts of the leaves, stembark and root of Ochrosia oppositifolia showed significant results of the disc-diffusion assay against Gram-positive bacteria. For instance, the leaf, stem-bark and root extracts gave the highest inhibition diameter zones against Grampositive bacteria of Staphylococcus aureus for both leaf and stem-bark extracts $(10.0 \pm 2.8,10.5 \pm 2.1 \mathrm{~mm})$ and MRSA for root extract $(14.0 \pm 1.8 \mathrm{~mm})$. Otherwise, there was no inhibition observed against Gram-negative bacteria of Vibrio cholera for root and stem-bark alkaloid extracts. Besides that, there were also no inhibition observed against one Gram-positive bacterium of Bacillus thuringiensis and one Gram-negative bacterium of Vibrio fluvialis for both leaf and stem-bark extracts (Table 1). These results were in agreement with the studies conducted by Damintoti et al. (2005), Jonathan et al. (2000), Masikaa and Afolayan (2002) and Tonia and Johannes (1997) which indicated that plant extracts inhibited mostly the Gram-positive bacteria compared to the Gram-negative bacteria.

It was reported that Gram-positive bacteria have a thick peptidoglycan layer with the absence of impenetrable cell wall compared to Gram-negative bacteria which have a thin peptidoglycan layer with the presence of impenetrable cell wall. Thus, Gram-positive bacteria do not have an effective barrier against the lipophilic solutes whereas the Gram-negative bacteria have an outer phospholipidic 
TABLE 1. Inhibition diameters of antibacterial activity for Ochrosia oppositifolia leaf, stem-bark and root alkaloid extracts at $10 \mathrm{mg} / \mathrm{mL}$

\begin{tabular}{lcccc}
\hline Bacteria & \multicolumn{3}{c}{ Inhibition diameter $(\mathrm{mm})$} & \multirow{2}{*}{$\begin{array}{l}\text { Positive } \\
\text { control* }\end{array}$} \\
\cline { 2 - 4 } & Leaf & Stem-Bark & Root & $16.7 \pm 0.1$ \\
\hline MRSA & $7.5 \pm 2.1$ & $7.0 \pm 1.4$ & $14.0 \pm 1.8$ & $14.3 \pm 1.2$ \\
Staphylococcus aureus & $10.0 \pm 2.8$ & $10.5 \pm 2.1$ & $11.5 \pm 1.2$ & $12.7 \pm 3.2$ \\
Bacillus subtilis & $8.5 \pm 3.5$ & $9.0 \pm 0.8$ & $9.5 \pm 2.1$ & $16.7 \pm 6.7$ \\
Bacillus thuringiensis & $\mathrm{NI}$ & $\mathrm{NI}$ & $7.0 \pm 0.6$ & $19.0 \pm 1.7$ \\
Staphylococcus typhimurium & $8.5 \pm 4.0$ & $8.5 \pm 2.1$ & $7.5 \pm 0.7$ & $22.7 \pm 0.6$ \\
Serratia marcescens & $7.5 \pm 0.7$ & $8.5 \pm 0.7$ & $10.5 \pm 0.7$ & $23.7 \pm 0.6$ \\
Escherichia coli & $7.5 \pm 2.1$ & $8.0 \pm 1.4$ & $7.0 \pm 1.4$ & $25.0 \pm 0$ \\
Vibrio fluvialis & $\mathrm{NI}$ & $\mathrm{NI}$ & $11.0 \pm 0.5$ & $10.0 \pm 0$ \\
Vibrio cholera & $7.0 \pm 1.4$ & $\mathrm{NI}$ & $\mathrm{NI}$ & \\
\hline
\end{tabular}

NI - No inhibition; *Antibiotic streptomycin $(10 \mu \mathrm{g})$ for all bacteria except Bacillus subtilis (penicilin, $30 \mu \mathrm{g}$ ) and Vibrio cholera (kanamycin, $30 \mu \mathrm{g}$ )

membrane that enables the cell wall to be impermeable to lipophilic solutes, while the porines constitute a selective barrier against hydrophilic solutes with an exclusion limit of about 600 Daltons (Nikaido \& Vaara 1985; Scherrer \& Gerhandt 1971). Many observations have confirmed these findings, but some findings have also showed that both Gram-positive and Gram-negative bacteria can be inhibited by the plant extracts (Suhanya et al. 2009). The study showed that methanolic and alkaloid extracts of Mitragyra speciosa leaves inhibit the growth of the Grampositive (Bacillus subtilis) and Gram-negative bacteria (Staphylococcus thyphimurium). This finding is also in agreement with the study conducted by Doughari (2006).

The MIC results in this study also agree with the above findings. The lowest MIC values for the alkaloid extracts were observed against Gram-positive bacterium of Bacillus subtilis and Gram-negative bacteria of Serratia marcescens and Staphylococcus thphymurium for both extracts of the leaves $(3.75 \mathrm{mg} / \mathrm{mL})$ and stem-bark $(0.94$ $\mathrm{mg} / \mathrm{mL}$ ) and Gram-negative bacterium of Vibrio fluvialis for root extract $(0.12 \mathrm{mg} / \mathrm{mL})$ (Table 2$)$. The MIC values at $\leq$ $0.064,0.128-0.512,1.023-0.513$ and $\geq 1.024 \mathrm{mg} / \mathrm{mL}$ were considered high, moderate, low and no activity (Kakuko et al. 2005). Therefore, from the MIC data obtained, the root alkaloid extract showed moderate antibacterial activity while the stem-bark alkaloid extract showed low antibacterial activity and the leaf alkaloid extract showed no antibacterial activity. Moreover, the root alkaloid extract showed the lowest MIC value against all bacteria tested compared to the leaf and stem-bark alkaloid extracts.

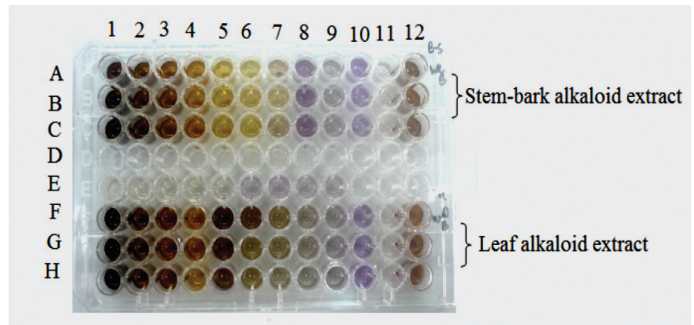

FIGURE 1. MIC determination for stem-bark and leaf alkaloid extracts of Ochrosia oppositifolia against Bacillus subtilis

Microtiter plate wells A1-A9, B1-B9, C1-C9 for triplicate of stem-bark alkaloid extract concentrations that range from 30 to $0.12 \mathrm{mg} / \mathrm{mL}$; F1-F9, G1-G9, H1-H9 for triplicate of leaf alkaloid extract concentrations that ranges from 30 to $0.12 \mathrm{mg} / \mathrm{mL}$; A10, B10, C10, F10, G10, H10 for negative control; A11, B11, C11,A12, B12, C12,F11, G11, H11, F12, G12, H12 for growth control; E1-E9 for positive control.

TABLE 2. Minimum inhibitory concentration for Ochrosia oppositifolia leaf, stem-bark, root alkaloid extracts and positive control

\begin{tabular}{lcccc}
\hline \multirow{2}{*}{ Bacteria } & \multicolumn{4}{c}{ MIC $(\mathrm{mg} / \mathrm{mL})$} \\
\cline { 2 - 5 } & Leaf & Stem-Bark & Root & Positive control $(\mu \mathrm{g} / \mathrm{mL})$ \\
\hline MRSA & 15 & 7.50 & 1.88 & 0.06 \\
Staphylococcus aureus & 7.50 & 1.88 & 0.94 & 0.25 \\
Bacillus subtilis & 3.75 & 0.94 & 0.94 & 8.00 \\
Bacillus thuringiensis & $\mathrm{NI}$ & $\mathrm{NI}$ & 3.75 & 0.25 \\
Staphylococcus typhimurium & 3.75 & 0.94 & 0.46 & 0.25 \\
Serratia marcescens & 3.75 & 0.94 & 0.46 & 0.25 \\
Escherichia coli & 7.50 & 7.50 & 0.94 & 0.25 \\
Vibrio fluvialis & $\mathrm{NI}$ & $\mathrm{NI}$ & 0.12 & 0.50 \\
Vibrio cholera & 7.50 & $\mathrm{NI}$ & $\mathrm{NI}$ & 0.50 \\
\hline
\end{tabular}




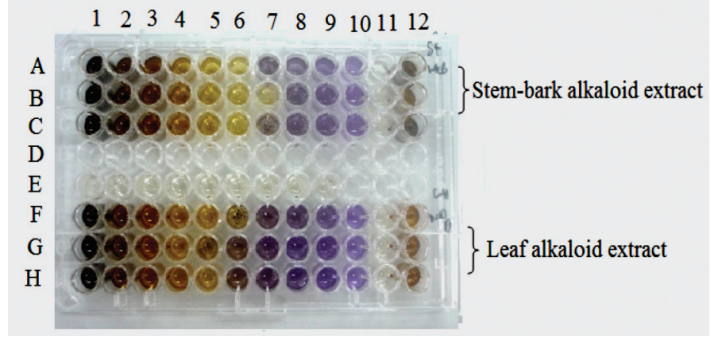

FIGURE 2. MIC determination for stem-bark and leaf alkaloid extracts of Ochrosia oppositifolia against

Staphylococcus typhimurium

Microtiter plate wells A1-A9, B1-B9, C1-C9 for triplicate of stem-bark alkaloid extract concentrations that range from 30 to $0.12 \mathrm{mg} / \mathrm{mL}$; F1-F9, G1-G9, H1-H9 for triplicate of leaf alkaloid extract concentrations that ranges from 30 to $0.12 \mathrm{mg} / \mathrm{mL}$; A10, B10, C10, F10, G10, H10 for negative control; A11, B11, C11, A12, B12, C12, F11, G11, H11, F12, G12, H12 for growth control; E1-E9 for positive control.

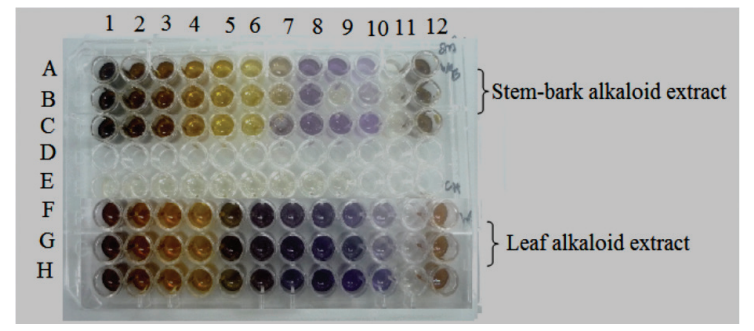

FIGURE 3. MIC determination for stem-bark and leaf alkaloid extract of Ochrosia oppositifolia against Serratia marcescens

Microtiter plate wells A1-A9, B1-B9, C1-C9 for triplicate of stem-bark alkaloid extract concentrations that range from 30 to $0.12 \mathrm{mg} / \mathrm{mL}$; F1-F9, G1-G9, H1-H9 for triplicate of leaf alkaloid extract concentrations that ranges from 30 to $0.12 \mathrm{mg} / \mathrm{mL}$; A10, B10, C10, F10, G10, H10 for negative control; A11, B11, C11, A12, B12, C12, F11, G11, H11, F12, G12, H12 for growth control; E1-E9 for positive control.

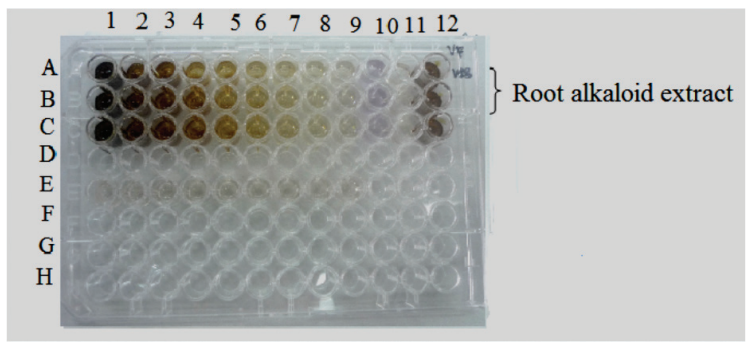

FIGURE 4. MIC determination for root alkaloid extract of Ochrosia oppositifolia against Vibrio fluvialis
Microtiter plate wells A1-A9, B1-B9, C1-C9 for triplicate of root alkaloid extract concentrations that range from 30 to $0.12 \mathrm{mg} / \mathrm{mL}$; A10, B10, C10, F10, G10, H10 for negative control; A11, B11, C11, A12, B12, C12 for growth control; E1-E9 for positive control.

\section{CONCLUSION}

In conclusion, the leaf, stem-bark and root alkaloid extracts showed sensitivity against both Gram-positive and Gram-negative bacteria. The root alkaloid extracts showed more potent antibacterial activity in contrast to leaf and stem-bark alkaloid extracts. Furthermore, the leaf and stem-bark alkaloid extracts demonstrated similar activities against the same bacteria with slightly different values of inhibition zones. This similarity might be due to the presence of neisosposinine and reserpinine alkaloids in both extracts which was shown in the previous study (Nasab 2013, 2012). Further isolation of the active chemical components of the root alkaloid extract is now under progress and it is predicted that there will be the presence of indole alkaloids but with different chemical structures as compared to the indole alkaloids in stembark and leaves extracts.

\section{ACKNOWLEDGEMENTS}

We would like to thank Universiti Kebangsaan Malaysia (UKM) and the Ministry of Higher Education (MOHE), Malaysia for allocating the grant DLP-2013-18 for this research. Thanks also go to all the lecturers of the School of Chemical Sciences and Food Technology and School of Biosciences and Biotechnology UKM for their continuous support, encouragement and valuable ideas. We would also like to express our gratitude to all laboratory assistants especially of the Laboratories L126 (Chemistry building) 3148, 3146 (Biology building), undergraduate and postgraduate students at the laboratories for their assistance in laboratory works.

\section{REFERENCES}

Burkhill, I.H. 1966. Dictionary of the Economic Products of the Malay Peninsula. Kuala Lumpur, Malaysia: Government of Malaysia and Singapore by the Ministry of Agriculture and Cooperatives. p. 1597.

CLSI. 2011. Clinical and Laboratory Standard Institute Performance Standards for Antimicrobial Susceptibility Testing. Pennsylvania, United States of America: National Committee for Clinical Laboratory Standards. M100-S21.

CLSI. 2009. Clinical and Laboratory Institute Performance Standards for Antimicrobial Disk Susceptibility Tests. Pennsylvania, United States of America: National Committee for Clinical Laboratory Standards. M02-A10.

Culvenor, C.C.J. 1963. A field method for alkaloid screening of plants. Journal of Pharmaceutical Sciences 53: 303-306.

Damintoti, K., Aly, S., Antonella, C., Saydou, Y., Carla, M., Jacques, S., Vittoria, C. \& Alfred, S.T. 2005. Antibacterial activity of alkaloids from Sida acuta.Journal of Biotechnology 4(12): 1452-1457. 
Doughari, J.H. 2006. Antimicrobial activity of Tamarindus indica Linn. Tropical Journal of Pharmaceutical Research 5(2): 597-603.

Gamble, J.S. 1922. Manual of Indian Timbers: An Account of the Growth, Distribution and Uses of the Trees and Shrubs of India and Ceylon, with Description of Their Wood Structure. London: Sampson Low, Marston and Company. p. 482.

Gurib, F.A. \& Brendler, T. 2004. Medicinal and Aromatic Plants of Indian Ocean Islands: Madagascar, Comoros, Seychelles and Mascarenes. Stuttgart, Germany: Medpharm.

Hadi, S. \& Bremner, J. 2001. Initials studies on alkaloids from Lombok medicinal plants. Molecules 6: 117-129.

Irith, W., Kai, H. \& Robert, E.W.H. 2008. Agar and broth dilution methods to determine the minimal inhibitory concentration (MIC) of antimicrobial substances. Nature Protocols 3: 163-175.

Jennifer, M.A. 2006. Determination of Minimum Inhibitory Concentration. Brimingham: Department of Microbiology, City Hospital NHS Trust. p. 2-12.

Jonathan, E.K., Anna, K.J. \& Johannes, V.S. 2000. Zulu medicinal plants with antibacterial activity. Journal of Ethnopharmacology 69(3): 241-246.

Jordan, W.H.G. 1965. The Alkaloids of Sandwicensis A. Hawaii: University of Hawaii.

Kakuko, Y., Fumiko, A., Arioki, N., Hikaru, O., Lucio, L.P., Edith, L.V., Elizabeth, E.M., Abigail, A. \& Ricardo, R.C. 2005. Antibacterial activity of crude extracts from Mexican medicinal plants and purified coumarins and xanthones. Journal of Ethnopharmacology 97: 293-299.

Kartini, A., Noel, F.T., Abdul, H.A.H., Mat, R.M., Khalif, M., Mohd, A.N., Koichi, T., Hiroshi, M., Marc, L., Hiroko, A. \& Khalijah, A. 2010. Oppositinines A and B: New vascorelaxtant $\beta$-carboline alkaloids from Neisosperma oppositifolia. Chemical \& Pharmaceutical Bulletin 58(8): 1085-1087.

Nasab, M.F. 2012. Chemical Constituents and Antiplasmodial Activity of Indole Alkaloids from Ochrosia oppositifolia. Kuala Lumpur, Malaysia: University of Malaya.

Nasab, M.F., Abdul, H.A.H., Aty, W., Halfatrius, E., Nugroho, C. \& Hiroshi, M. 2013. Indole alkaloids from the stem bark of Ochrosia oppositifolia (Apocynaceae) with antiplasmodial activity. The Japanese Society of Pharmacology 67(2): 65-66.

Neli, L.P., Yogendra, K., Berington, M., Ranjan, K.B. \& Santaram, J. 2011. In vitro antibacterial activity of alkaloid extract from stem bark of Mahonia manipurensis Takeda. Journal of Medicinal Plant Research 5(5): 859-861.

Nikaido, H. \& Vaara, M. 1985. Molecular basis of bacterial outer membrane permeability. Microbiological Reviews 1: 1-32.

Masikaa, P.J. \& Afolayanb, A.J. 2002. Antimicrobial activity of some plants used for the treatment of livestock disease in eastern cape, South Africa. Journal of Ethnopharmacology 83: $129-134$.

Ridley, S.N. 1894. The Concise Flora of Singapore Gymnosperms and Dicotelydons. Singapore: University Press National University of Singapore.
Scherrer, R. \& Gerhardt, P. 1971. Molecular sieving by the Bacillus megaterium cell wall and protoplast. Journal Bacteriol 107: 718-735.

Scorzoni, L., Benaducci, T., Almeida, A.M.F., Silva, D.H.S., Bolzani, V.S. \& Mendes, G.M.J.S. 2007. Comparative study of disk diffusion and microdilution methods for evaluation of antifungal activity of natural compounds against medical yeasts Candida spp and Cryptococcus sp. Journal of Basic and Applied Pharmaceutical Sciences 28(1): 25-34.

Stevens, M.G. \& Olsen, S.C. 1993. Comparative analysis of using MTT and XTT in colorimetric assays for quantitating bovine neutrophil bactericidal activity. Journal of Immunological Methods 157(1-2): 225-231.

Suhanya, P., Juzaili, B.A., Surash, R., Sabariah, I., Sreenivasan, S., Mohd, I.M.S. \& Sharif, M.M. 2009. Evaluation of antioxidant and antibacterial activities of aqueous, methanolic and alkaloid extracts from Mitragyna speciosa (Rubiaceae Family) leaves. Molecules 14: 3964-3974.

Susiarti, S. 2006. Pengetahuan dan pemanfaatan tumbuhan ubat di Sabong-Pulau Weh, Nangroe Aceh Darussalam. J. Tek. Ling Special Edition: 198-209.

Svobodo, G.H., Poore, G.A. \& Montfort, M.L. 1968. Alkaloids of Ochrosia maculate Jacq. (Ochrosia borborica Gmel) isolation of the alkaloid and study of the anti tumor properties of 9-Methoxyellipticine. Journal of Pharmaceutical Sciences 57(10): 1720-1725

Tonia, R. \& Johannes, V.S. 1997. Antibacterial activity of South African plants used for medicinal purposes. Journal of Ethnopharmacology 56(1): 81-87.

Van Valkenberg, J.L.C.H. \& Bunyapraphatsara, N. 2001. Plant resources of South-East Asia No. 12(2). Medicinal and poisonous plants 2. Backhuys Publishers, Leiden, The Netherlands. Nordic Journal of Botany 21(6): 580.

Puteri I.A.M. Mahmud* \& W.A. Yaacob School of Chemical Science and Food Technology Universiti Kebangsaan Malaysia 43600 UKM Bangi, Selangor Darul Ehsan Malaysia

Nazlina Ibrahim

School of Biosciences and Biotechnology

Universiti Kebangsaan Malaysia

43600 UKM Bangi, Selangor Darul Ehsan

Malaysia

*Corresponding author; email: put3ili@gmail.com

Received: 27 July 2016

Accepted: 3 January 2017 